\title{
自動車へのワイヤレス電力伝送技術の動向と 安全性へのシステム設計
}

\author{
高橋 俊輔 $*$
}

\section{The Trend of the Wireless Power Transfer Technology for EV and Systems Architecture to Safety}

\author{
Shunsuke TAKAHASHI*
}

* 早稲田大学電動車両研究所（广 169-8555 東京都新宿区大久保 3-4-1 55 号館 S 棟 704)

*WASEDA University Research Institute of Electric-driven Vehicles (S-55-704, 3-4-1 Okubo, Shinjuku-ku, Tokyo 169-8555)

\section{1. 自動車用ワイヤレス電力伝送技術}

\section{1 ワイヤレス給電方式}

ワイヤレス給電システムには各種方式があり, 図 1 にそ の伝送電力と伝送距離の関係を示すが, 出力 $3 \mathrm{~kW}$ 200 $\mathrm{kW}$, ギャップ $5 \mathrm{~cm} \sim 40 \mathrm{~cm}$ が必要な電気自動車 (EV) およ び電動バス (e-Bus) に使用可能なものとして,

·電磁誘導式

- 磁界共振式

の 2 種類が挙げられる。電波式やレーザー式も電力伝送可 能だが，人体防護の観点から現法規の下では使用できない。

1.1.1 電磁誘導式

1831 年にイギリスの Michael Faraday が見出した, 静止 している導線の閉じた回路を通過する磁束が変化すると, その変化を妨げる方向に電流を流そうとする電圧が生じる と言うファラデーの電磁誘導法則に基づき, 対向させたコ イルと磁束収束用の磁性体を用い, 1 次 $/ 2$ 次コイル間に共 通に鎖交する磁束を利用する電磁誘導式は, 図 2 に示すよ うにギャップのある変圧器である。

1 次コイルに交流電流を流すとコイル周囲に磁界が発生, 1 次 $/ 2$ 次コイルを共通に鎖交する磁束により 2 次コイルに 誘導起電力が発生する。理想的な変圧器では 1 次コイルの 磁束は全て 2 次側に伝えられ, 両コイルの磁束伝達度合い $\phi_{2} / \phi_{1}$ を示す結合係数 $\mathrm{k}$ は 1 である。しかし, ギャップがあ る場合には漏れ磁束が発生, $\mathrm{k}$ は 1 よりも小さくなる。こ の漏れ磁束が 1 次 $/ 2$ 次側の自己インダクタンスにそれぞ れ直列に接続された漏れインダクタンスとして, チョーク コイルと等価な働きをする。

つまり, ワイヤレス給電は変圧器に比べ励磁インダクダ ンスが小さく, 漏れインダクタンスによる電圧降下が大き いシステムとなるため, 大ギャップでも電力を効率よく伝 達するために, 1 次側の印加周波数を高周波にして 2 次誘 起電圧を上げたり, コイルのインダクタンスにコンデンサ を並列もしくは直列に接続した共振回路を設けている。た だ電磁誘導式は結合係数に大きく依存しているため, $\mathrm{k}$ が

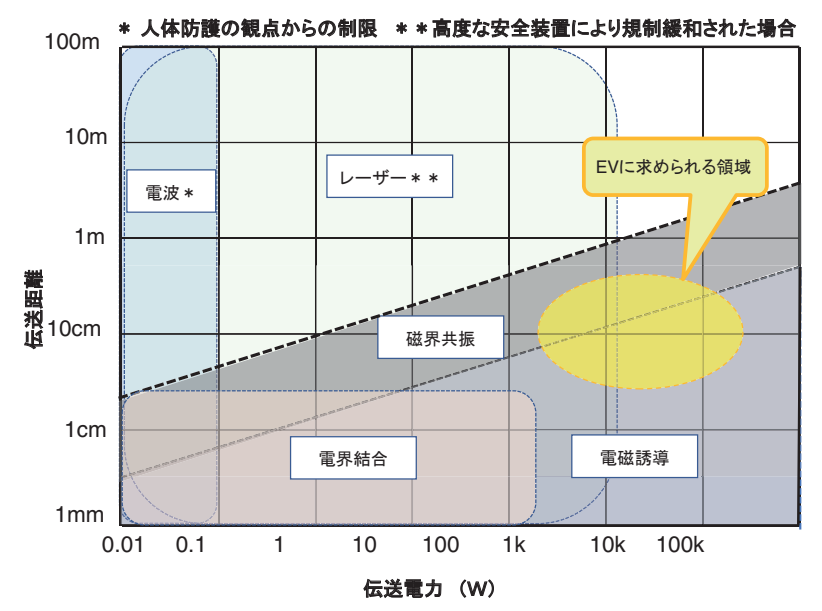

図 1. 各方式の伝送電力と伝送距離

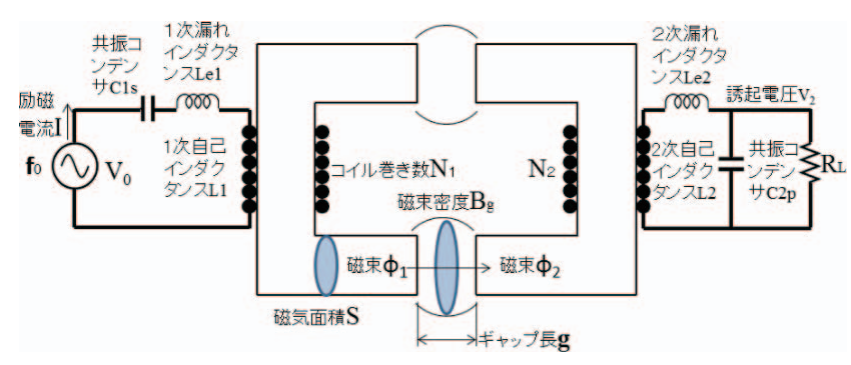

図 2. 電磁誘導式の基本原理

0.01 以下になるような, 極端な大ギャップでは電力伝送が できない。

\subsection{2 磁界共振式}

磁界共振式は, 2007 年にアメリカ Massachusetts Institute of Technology (MIT) の研究チームが, 2 m 離れた距離で 60 $\mathrm{W}$ の電力伝送に成功したことで注目を浴びた。図 3 に MIT が発表したシステムの概要を示すが, 先ず変圧器とイン ピーダンス変換器の役目をする 1 次側の 1 ターンループコ イルから密な電磁結合により送電側のヘリカルコイルに電 力伝送する。1 次 $/ 2$ 次側のヘリカルコイルの性能係数 $\mathrm{Q}$ を高い值にして, 同じ周波数で LC 共振させ, 空間に蓄積 される磁気エネルギを利用する磁気共鳴の技術で電力伝送 


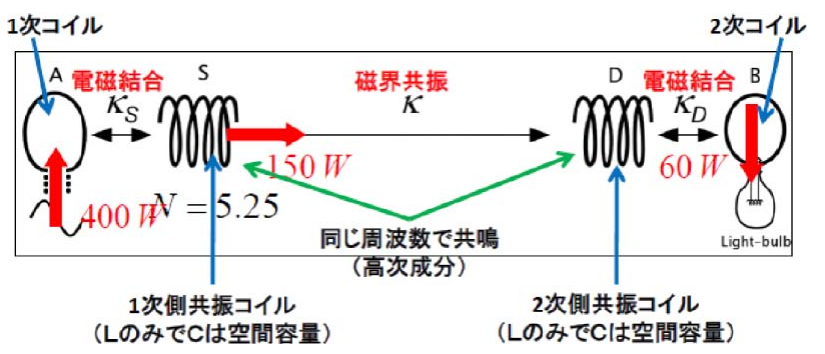

図 3. MIT が発表したシステムの概要

している。2 次側は 1 次側と同じコイル構成となっている。 当初のコイルは図のように送受電とも2 コイル構造で, 周波数も数 $\mathrm{MHz}$ だったが, 現在使われているシステムで はコイルは電磁誘導式と同じ 1 コイル構造であり, 電源も インバータを使って周波数も数十 $\mathrm{kHz}$ となっている。1 次 コイルから放射される磁束を直接 2 次コイルに鎖交させれ ば前述の電磁誘導式となるが, 1 次 $/ 2$ 次側の磁束が殆ど鎖 交していない $\mathrm{k}$ が 0.01 以下となるよう両コイルを十分に離 した状態で, 磁界共振式は電磁誘導式と殆ど同じシステム を使いながら両コイルサイズと波長，磁界分布をうまく制 御してエネルギを伝送している。そのためコイルサイズ, 波長, 伝送距離に一定の制約が生まれ, その制約条件が崩 れると共鳴が起こらず電力伝送ができなくなる。そこで, 今では磁界共振式は電磁誘導式の 1 種であると考えられて いる。

\section{2 ワイヤレス給電の動向}

\subsubsection{EV 用ワイヤレス給電}

国内では 2014 年頃まで日産自動車やトヨタ自動車, 三菱 自動車, 本田技研工業が出力 $2 \mathrm{~kW} \sim 3.3 \mathrm{~kW}$, 周波数 85 $\mathrm{kHz}$ の磁界共振式のものを自社の $\mathrm{EV}$ やプラグインハイブ リッド車 $(\mathrm{PHV})$ に搭載して発表, 各地で実証試験を盛んに 行っていたが，最近では殆ど発表が見られない。

海外では 2016 年のパリモーターショーで Daimler がコン セプトカーGeneration EQ に Qualcomm/Brusa 製の $3.6 \mathrm{~kW}$, $85 \mathrm{kHz}$ のコイルを搭載したり, Mercedes-Benzの PHV S550e に搭載して発売予定と言う発表をし, Volkswagen も EV 向 け新プラットフォームの前軸のすぐ後ろに受電コイルを搭 載するコンセプトを発表している。自動車メーカに直接部 品を供給する 1 次請けの Bosch も 2017 年に図 4 のように BMW の i3 の前軸の直ぐ後ろの丸印の所に標準化ステージ

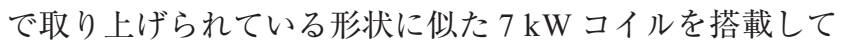
発表し, 2018 年には Mercedes-Benz に搭載して市販する予

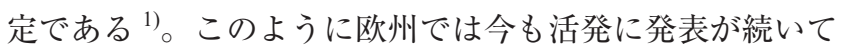
いる。

日本と海外との対応の違いはワイヤレス給電システムの 標準化にある。グローバルな EVへのワイヤレス給電シス テムでは仕様の標準化・規格化が必要で, 上記のような動 きを受けて IEC/ISO を中心に日米欧で標準化が進められて いて, コイル形状は Circular 型, 周波数は $85 \mathrm{kHz}$ 帯に絞ら

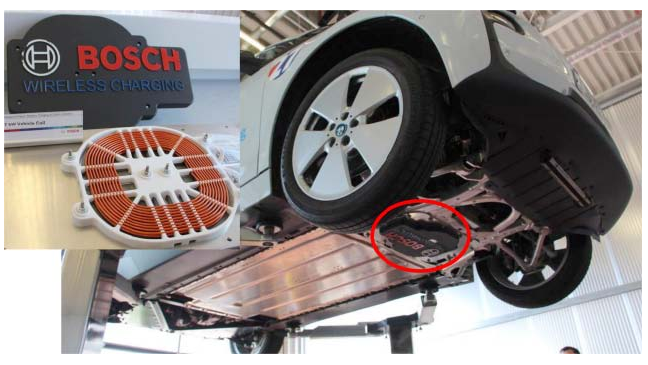

図 4. Bosch 社が搭載したワイヤレス給電用受電コイル

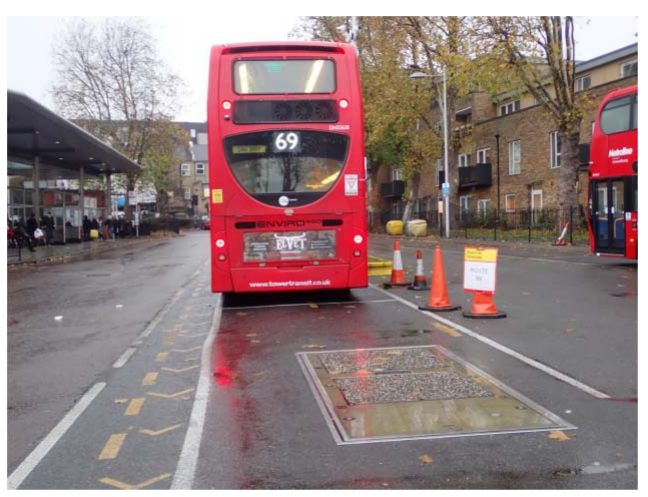

図 5. ワイヤレス給電地上コイルと 2 階建て電動バス

れ，その他の規格も2019年末までにまとまる可能性があ る。自動車会社での開発は大方終了し，日本の会社は標準 化が済んだ仕様のものを搭載して，顧客対応しょうとして おり，海外では制定中の規格に自らの仕様を押し込もうと いう考えがあるからと思われる。

1.2.2 e-Bus 用ワイヤレス給電

国内では 2011 年以来, 早稲田大学が $7 \mathrm{~m}$ 長のバスを電動 化したWEB シリーズに $30 \mathrm{~kW} ， 22 \mathrm{kHz}$ と $44 \mathrm{~kW}, 85 \mathrm{kHz}$ のコイルを搭載して長野市や川崎市で長期にわたる実証運 行を行った 2),3)。また, 国土交通省や東京都も2008 年以 降, $12 \mathrm{~m}$ 長の PHV 路線バスに $50 \mathrm{~kW}, 22 \mathrm{kHz}$ のコイルを 搭載して羽田空港，東京ビッグサイトや東京駅で実証運行

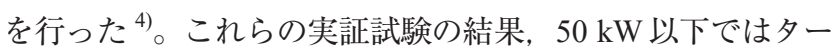
ミナルでの充電に時間が掛かり過ぎダイヤを確保できない ため，ディーゼルバスを e-Bus で置き換えるには，少なく とも $90 \mathrm{~kW}$ 以上の送電電力が必要と言う結論を得るに至 り，実証試験のみで終わっている。

海外では殆どの事例が $100 \mathrm{~kW}$ 以上の大電力システムを 採用している。2014 年からイギリス Milton Keynes 市は 8 台の $9 \mathrm{~m}$ 長の e-Busに IPT Technology（IPTを開発した Wampflerの関連会社）の $120 \mathrm{~kW}, 20 \mathrm{kHz}$ の IPT を搭載し て， $24 \mathrm{~km}$ 路線のディーゼルバスを全て e-Busに置き換え て運用を続けている。また，図 5 に示すようにLondon市 は2016 年から $100 \mathrm{~kW}$ の IPT を用いて郊外の $11 \mathrm{~km}$ 路線で $12 \mathrm{~m}$ 長の 2 階建て e-Busに給電して運用を行っている。 Bombardierは $200 \mathrm{~kW}, 20 \mathrm{kHz}$ のシステムを $12 \mathrm{~m}$ 長の e-Bus と $18 \mathrm{~m}$ 長の連接 e-Bus に搭載して, 2013 年以降ドイツの 
Braunschweig市, Berlin市やベルギーの Bruges 市などで実 運用を続けている。中国でも通信機器大手の ZTE が 2015 年から大ギャップの $120 \mathrm{~kW}, 85 \mathrm{kHz}$ システムを $9 \mathrm{~m}$ から $12 \mathrm{~m}$ の e-Bus に搭載し, 道路上などで充電し, 1 充電で鄭 州市では $44 \mathrm{~km}$, 襄陽市では $23 \mathrm{~km}$ の長距離運用を行って いる。以上のように海外の $100 \mathrm{~kW}$ 以上のシステムは全て 実運用されている ${ }^{5)}$

\section{2. 安全性へのシステム設計}

ワイヤレス給電システムの要求仕様を満たす設計, 製 作, 試験, 完成までの流れを IT 製品開発の手法の一種であ る $\mathrm{V}$ モデル風に示すと図 6 のようになる。製作までの設 計・検証のステージと完成までの試験・妥当性検討ステー ジに分けられ，それぞれのステージでの安全性へのシステ ム設計について以下に示す。

\section{1 設計・検証ステージ}

ワイヤレス給電の黎明期には膨大な量の物理計算式を解 いて求めた設計に基いて製作, 試験をして, 問題が生じた ら再度時間を掛けて設計，製作をする方法を採っていた。 しかし，コンピュータとシミュレーション技術が発達した 昨今では，それぞれの設計ステージで最適なシミュレー ションによりモデルベースを検証して最適設計をするシス テムを採用することで, 設計から製作までの時間およびコ ストの低減を眓かっている。

シミュレータとしてオームの法則やキルヒホッフの法則 のような集中定数系のものと, 特性インピーダンスと言っ た伝送経路理論を元にする分布定数系のもの，およびマク スウェル方程式に基づく 2 次元や 3 次元回路系のものがあ る。なお, 分布定数系のものは高周波回路シミュレータで 解析できるが，本章で扱う EV 用システムの周波数帯での 適用は無いと思われるため, 解説は省略する。

\subsection{1 回路シミュレータ}

集中定数系の電子回路のアナログ動作シミュレーション ツールとしては, 1973 年に California 大学 Berkeley 校で開 発された Spice (Simulation Program with Integrated Circuit Emphasis) が使われることが多い。図 2 における共振コンデ ンサの配置には 1 次 $/ 2$ 次コイルそれぞれに直列あるいは 並列にした方式がある。これらは一概にどれが良いと言え るものではなく, 使用する周波数やコイル, ギャップ, 負 荷などの条件によって決まる。また共振コンデンサを直並 列に配置することもあるため, 図 7 のようにSpice などの 回路シミュレーションを駆使することによって周波数特性 だけでなく過渡特性を含め最適な方式を設計することが可 能だが，パラメータが多くなると最適解を求めるにはかな りの時間が必要な場合もある。電源回路や充電回路も含め てワイヤレス給電の電気回路全てのシミュレーションが可 能である。

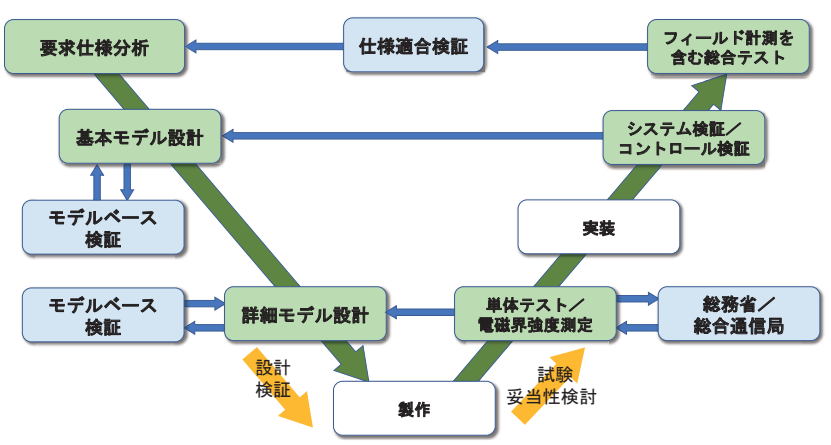

図 6. ワイヤレス給電システムの設計検証と妥当性検討の 開発フロー

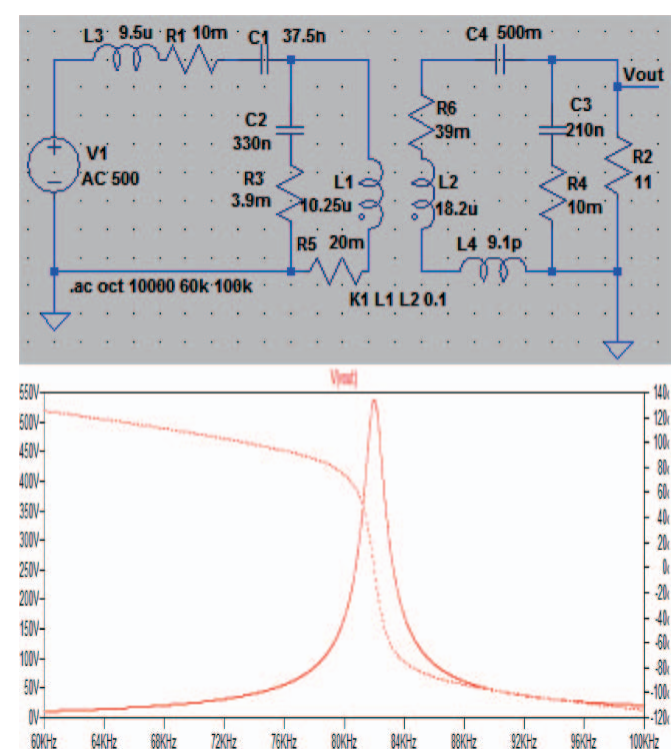

図 7. Spice による回路シミュレーション例

\section{1 .2 電磁界シミュレータ}

マクスウェル方程式に基づく 2 次元や 3 次元回路系の電 磁界解析は有限要素法や時間領域差分 (Finite-difference timedomain: FDTD) 法などの電磁界シミュレータを使うことで 解くことができ, 結果を 2 次元や 3 次元の画像として得ら れる。

コイルサイズや波長，伝送距離に一定の制約がある磁界 共振式では，使用周波数によりコイル形状や回路を最適な ものに設計する必要がある。コイル間の空間にどのように 磁界が発生して電力を送電するのか, 両コイルの位置関係 を変えると効率がどのように変化をするかを計測で視覚化 することは困難なため, 磁界解析により送電状態での磁束 密度分布を図 8 のように再現して，最適なコイル設計がで きる。

また，実測困難な電流分布を有限要素法で解析し，電流 により形成される磁界からインダクタンスを求めることが でき，コイルを実際に巻かなくても図面からインダクタン スを推定できる。

2 次コイルには, すぐれた磁気シールドも求められる。 

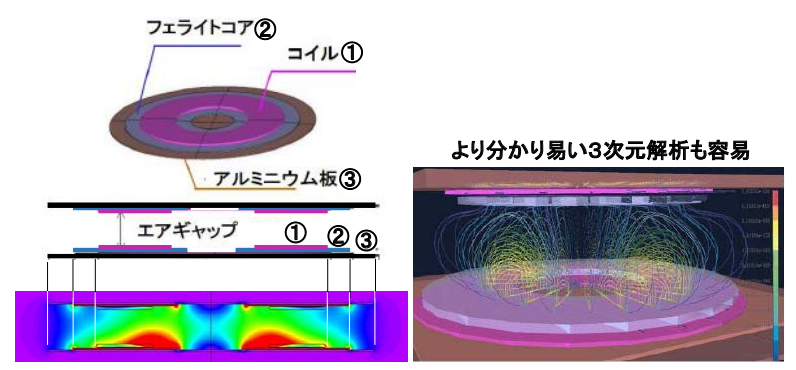

図 8. 電磁界シミュレーションによるコイル間の磁束密度 状況

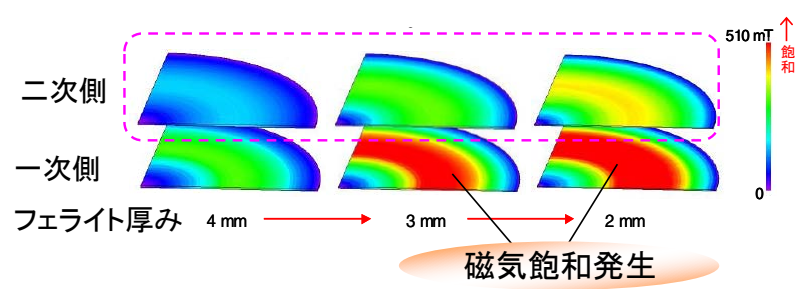

図 9. 電磁界解析によるフェライトの磁気飽和検討例

EV e-Bus における 2 次コイルの設置場所は床下となる。 この場合, 1 次コイルから送られてくる高周波磁束が 2 次 コイルを通り越して車体の金属部分に渦電流を発生させる 恐れがあり, 図 4 のように 2 次コイルの直ぐ横に電池が設 置されていると, 電池の金属面が渦電流により異常発熱を 起こして電池が発火する恐れもある。この問題の解決に は, 図 8 のようにアルミニウム板で磁気シールドを行うこ とで, 1 次 $/ 2$ 次コイルの上下方向への漏洩磁束が少なくな ることが左下のシミュレーション結果で見て取れる。

また，コイル部のコア材質には高周波のためフェライト を使用するが, 図 9 のような電磁界解析を行って, 最適な コア配置や磁気飽和および異常な発熱を生じない設計をす る必要がある。

高周波においては導線の表面を電流が流れようとする表 皮効果があり，コイルの抵抗やインダクタンスが影響を受 けるため, 細い導線を多数束ねたリッツ線を使用すること で表面積を増して抵抗を下げている。有限要素法を用いた 磁界解析により図 10 のようにリッツ線内の電流分布の偏り やジュール損失を正確に求めることができ, リッツ線の撚 り方を検討したり逆位相電流の流れ易い中心線を非導体に することなどで，コイル性能を上げる設計が可能になる。

コンバータやインバータ, 整流部の電力供給ラインでは 配線の断面積確保のためバスバーが使われる。バスバーを 流れる高周波電流でもリッツ線同様に, 表皮効果による影 響が無視できず，抵抗や損失の増加が問題となる。温度や 電流分布を考慮した設計が重要になるが, バスバーの形状 は複雑なため, 電流通電時にどの場所に電流が偏って流 れ，発熱源として効くのかを事前に予測するのは難しい。 電磁界解析の結果から図 11 のように角部を作らず電流が流 れやすい形状にすると電流の偏りによる局所加熱が少なく

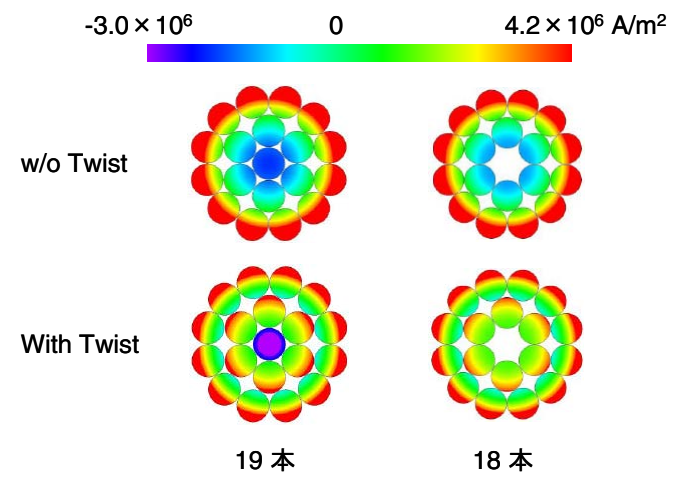

図 10. 電磁界解析によるリッツ線の電流分布

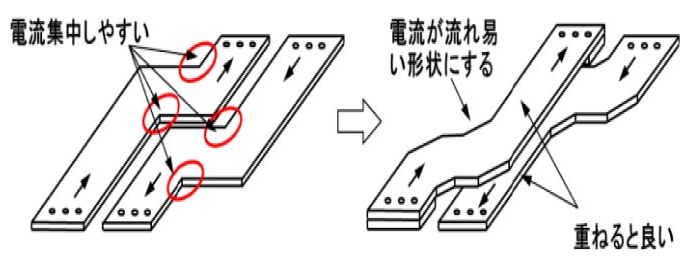

図 11. バスバーの構造

なることが分かる。また, 表皮効果, 近接効果の影響を低 減するには，バスバーを重ねて実装すると大きな効果があ ることもわかる。

このようにワイヤレス給電システムの設計においては, 電磁界解析は非常に重要なツールになる。

\section{2 試験・妥当性検討ステージ}

単体およびシステムへの試験・妥当性検討は要求仕様と の適合を検証し，設計モデルベースへのフィードバックの ためにも重要なものである。その中で安全性に関するもの を示す。

\subsection{1 電磁界強度測定}

ワイヤレス給電はエネルギ伝送に必要なワイヤの制約か ら解放されるメリットの反面, 空間に放出されるエネルギ による電磁環境が他のシステムに影響を及ぼす可能性が存 在するため, 電磁両立性 (Electro Magnetic Compatibility: EMC) の確立が課題であり，使用に当たっては各国の電波 法などの規制を受ける。わが国では高周波利用設備として 電波法第 100 条 2 項と電波法施行規則第 45 条 3 項により $10 \mathrm{kHz}$ 以上の高周波電流を利用して出力が $50 \mathrm{~W}$ を超える ものは，各地の総合通信局に設置許可申請を提出して個別 に許可を受ける必要がある。しかしながら，1台ごとに設 置申請／許可をしていたのでは普及の足かせになってしま う。そこで，ワイヤレス給電を対象にした明確な規制やカ テゴリーを決めるため, 2013 年 6 月から総務省の電波利用 環境委員会にて利用可能な周波数と発生する電磁波の許容 值などに対する制度化が検討され，2016 年 3 月に高周波利 用設備の型式指定の一部を改正する省令が出された。この 省令の中で, 家電機器用のものとともに世界に先駆け EV 用ワイヤレス給電システムにも型式指定の道が開かれたこ 
とは画期的なことである。型式の指定が行われる条件とし て, 電力伝送方式は磁界結合方式 (電磁誘導式, 磁界共振 式), 伝送電力は $3 \mathrm{~kW}$ 程度 (最大 $7.7 \mathrm{~kW}$ ), コイル間距離 は $0 \sim 30 \mathrm{~cm}$ 程度で, 周波数は $79 \mathrm{kHz} \sim 90 \mathrm{kHz}$ である。

EMC は狭義には無線通信や電子機器への干渉の問題であ るが, 広義には人体への影響の問題も含まれ，人体曝露に 関する防護指針を満たすように世界各国で法制化されてい る。わが国では総務省の電波防護指針に示されているが, 一般的には WHO が推奨する国際非電離放射線防護委員会 (ICNIRP) のガイドラインに従い, 使用周波数ごとのガイド ライン数值以下にする必要がある。 EV 用ワイヤレス給電 システムに使われる周波数 $100 \mathrm{kHz}$ 以下での漏洩磁界許容 值は 1998 年版の ICNIRP では $6.25 \mu \mathrm{T}$ であったが, 2010 年 版では $27 \mu \mathrm{T}$ 以下と緩和されている。

測定例を示すと, 電磁放射が大きいと言われるソレノイ ド型の周波数 $85 \mathrm{kHz}, 44 \mathrm{~kW}$ 出力コイルを $7 \mathrm{~m}$ 長 e-Busに 搭載し, ギャップ $10.5 \mathrm{~cm}$ に扔ける充電時のバス車内での 磁束密度は, コイルの磁束方向にある座席での数值が高 かったが，それでも最大值は約 $1.1 \mu \mathrm{T}$ と十分に小さいもの であった6。

\subsection{2 コイル間の異物検知システム}

ワイヤレス給電システムは，1 次コイルから空間に放出 される電磁波を抑えるため, 2 次コイルが無い状態では 1 次コイルに通電しないようなインターフェイスを設けてい る。しかしながら，2 次コイルが1次コイル上にあって電 力伝送をしている状態で, コイル間に渦電流を生じやすい 形状の金属を入れると, 図 12 の例のように, $10 \mathrm{~kW}$ 出力に おいて金属夕ワシが 1 分後に $200^{\circ} \mathrm{C}, 8$ 分後に $375^{\circ} \mathrm{C}$ まで 上昇してしまう。そこで何らかの有効な異物検知 (Foreign Object Detection: FOD) システムの搭載が必要となる7)。

IEC/ISO 主導で進められている EV 用ワイヤレス給電シ ステム標準化ステージで, FOD は必須機能として論議され ている。2013 International CES で Qualcomm Halo が FOD 機 能の付いたシステムを発表している。1 次コイル表面にルー

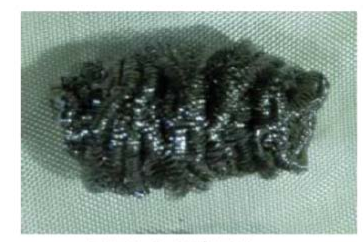

ステンレスタワシ

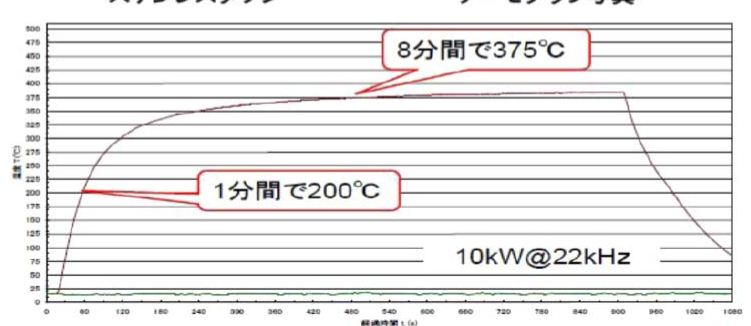

図 12. 異物による誘導加熱実験結果
プ状にメッシュを切ったアレイ板を貼り，そのループに微 弱な電流を流しておき，金属がコイル上にある場合での電 流の変化を検知して送電動作を停止するようにしている。 これを使うことで貨幣のような小さな金属も検知，ドライ バーのスマホに知らせることができる ${ }^{8)}$

\section{3. おわりに}

自動車へのワイヤレス給電システムは e-Bus では既に実 用に供されていて，EVでも国際標準規格が制定されれば いつでも世に出る状況になっている。これらのシステムの 設計にあたっては各種解析ソフトを駆使することで，運用 中の過熱や発火対策に向けて十分な検討がなされている。 また，各種試験でもその安全性は確認されている。

(2018.5.8- 受理)

\section{文献}

1) http://response.jp/article/2017/07/06/297072.html?gp=1_ email_20170706

2）紙屋雄史, 高橋俊輔, 大聖泰弘：“短距離走行・高頻度充電 型電動バスの性能評価（第 1 報）一開発車両の長期営業運行 中に得られた非接触給電装置に係る各種データの詳細分 析一, ”自動車技術会論文集, Vol. 46, No. 2, 20154213, pp. $367-372,2015$

3）三輪希己，呉哲棟，楊翔，紙屋雄史，大聖泰弘，井原雄 人, 尾林秀一, 武 俊介: “短距離走行・高頻度充電コンセ プトを採用したワイヤレス給電型電気バスの設計・試作な らびに公道走行実証試験に基づく性能評価,”自動車技術会 2016 年度学術研究講演会前刷集, P, No. 6, pp. 1-4, 2017

4) 国土交通省都市局・自動車局：“電気バ久導入ガイドライ ン,” 2012

5) 高橋俊輔：“大型車両へのワイヤレス給電の動向と課題, ” 電子情報通信学会 2018 年総合大会講演論文集, BI-9-4, pp. SS53-SS64, 2018

6) 平成 28 年度環境省委託事業：“EV バス早期普及にむけた充 電設備を乗用車と共有するワイヤレス充電バスの実証研究 成果報告書, ”東芝, 2017

7) 高橋俊輔：“自動車の無線電力伝送技術と EMC, ” 科学情報 出版, EMC, Vol. 27, No. 10, pp. 51-65, 2015

8) http://www.nikkei.com/article/DGXNASFK1103R_R10C $13 \mathrm{~A} 1000000$

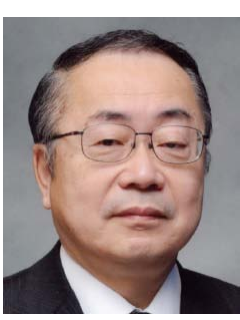

高橋俊輔（たかはししゅんすけ）

著者紹介

1972 年早稲田大学大学院理工学研究科卒。三井造 船勤務時代よりワイヤレス給電を手掛け，2003 年 から昭和飛行機工業にて e-Bus およびそのワイヤ レス給電システムの開発プロジェクトに参画。 2013 年以降, 早稲田大学でワイヤレス給電システ ムの研究を続ける。 